\title{
Resource Mapping and Indexing of Federal \\ Provinces of Nepal: An Analysis
}

\author{
Chandra Lal Pandey* \\ Niraj Poudyal** \\ Dipesh Khadka**
}

\begin{abstract}
Nepal has entered into a federal political structure with 7 provincial governments and 753 local municipalities (rural and urban). There is a paucity of evidence on the status of resources available in the seven provincial governments without which, estimation of resource gap and potentials of these provincial governments for appropriate policy interventions remains elusive. In this paper, we have prepared a resource map of the provincial governments and developed a resource index so that we can rank the provinces using the index. The resource index includes the dimensions of human resource (population), natural resource (arable land, forest coverage and water resources) and financial resources (tax revenue generated per person and GDP per capita). Our findings suggest that there is a high disparity of resource availability in seven different provinces. Provinces 6 and 7 located in the mid and far western regions are found developmentally challenged with low revenue collection and high poverty rate and migration. Provinces 2 and 5 have high levels of resources, wastage and inefficiency. Province 4 is found to be outstanding in terms of efficient resource use and knowledge, and if supported with more resources possesses high chance of becoming the role model province in Nepal.
\end{abstract}

Key Words: Resource mapping, federal provinces, GDP, guided democracy, failed state, transformations

\section{Introduction}

The new constitution of Nepal 2015 envisages three levels of government system, namely, federal, provincial and local. The constitution also mandates that federal

* Dr. Pandey has done Postdoc and PhD from University of Waikato, New Zealand. Currently he is working as Program Coordinator and Asst. Professor of Community Development Program, School of Arts, Kathmandu University. His areas of expertise include issues of public policy, environmental policy, water and disaster governance and community development.

** Dr. Poudyal has earned PhD from Virginia Tech, USA. He works at Economics Program, School of Arts, Kathmandu University. His areas of expertise include Econometrics and Macroeconomics.

*** Mr. Khadka is a Research Assistant at School of Arts, Kathmandu University. He is currently engaged in disability research and teaching. 
government prioritize on developing national policies whereas the provincial governments prioritize development activities of the provinces and the local governments design and implement national, provincial and local priorities in cooperation and collaboration with federal and provincial governments (GoN, 2015). However, there is a paucity of consolidated data about various resources each of the province has with the potential of developing further based on the theory of comparative advantage. So, the estimation of resource gap and potentials of these provinces for appropriate policy interventions remains elusive.

In this paper, we have prepared a resource map of the provincial governments and develop a resource index so that we can rank the provinces using the index. The resource index includes the dimensions of human resource (population), natural resource (arable land, forest coverage and water resources) and financial resources (tax revenue generated per person and GDP per capita). We conducted our analysis based on following three research questions: 1) Are the resource rich provinces/districts likely to have better outcomes in terms of HDI? 2) Are there any inefficiencies and lessons to be learned in terms of resource use? 3) Which resources among human, natural and capital plays the most significant role to increase HDI?

\section{Background Study}

\section{Political Development in Nepal}

The pace of development is determined by the political system a particular country practices or evolves through. If the political system becomes favorable, immense overarching development can be promoted for betterment of the country (Dahal, 2005). In this section, we present the political history of Nepal contextualizing how centralized monarchy and Ranarchy transformed into a federal republic of Nepal and impacted its developmental paths and underutilization of resources. Physically, Nepal lies in South Asia along the southern slopes of the Himalayan mountain ranges. It is a landlocked country situated between the Tibet Autonomous region of China to the north and India to the east, south, and west. Its territory extends roughly 500 miles (800 kilometers) from east to west and 80 to 150 miles from north to south (Pandey, 2017). The capital of modern Nepal is Kathmandu located in the province no. 3 out of the 7 provinces.

Shahs and Ranas ruled Nepal for more than 200 years ever since the late King Prithivi Narayan Shah conquered Malla dynasty in Kathmandu and laid foundations for unified kingdom of Nepal. The position of the Shah dynasty was weakened by the fact that the two kings who ruled successively between 1777 and 1832 were minors when they ascended the throne, providing opportunities for the regents and the nobility to compete for political power, using the young rulers as puppets. The regents and nobility 
Resource Mapping........ Chandra Lal Pandey, Niraj Poudyal, Dipesh Khadka

strived for a monopoly of political power and offices for their families, with their rivals exterminated, exiled to India, or placed in a subordinate status. This was achieved by the Thapa family from 1806 to 1837 and even more extensively by the Rana family from 1846 to 1951 (Encyclopedia Britannica Inc., 2018). Since 1846, Nepal fell under the sway of hereditary Prime Ministers known as Ranas from Monarchy, who dominated the monarchy and cut off country from the outside world. Ranas captured natural resources of the country on the basis of privatization and individual wealth instead of overall national development.

In 1950, Anti-Rana forces of Nepal based in India formed alliance with King Tribhuvan to end Rana rule. The 1951 revolution replaced the century-old Rana oligarchy with a democratic dispensation through people's revolt supported by the then titular king (Panday, 2018). The sovereignty of crown was restored and the then revolutionary Nepali Congress Party also joined the government led by Rana Prime Minister. King Tribhuwan passed away in 1955 and King Mahendra ascended the throne. In 1959, first parliamentary election was held along with the adaptation of a new multi-party constitution but King Mahendra seized control on power and suspended parliament, the constitution and party politics after Nepali Congress Party (NCP) wins elections with B. P. Koirala as Prime Minister in 1960. A new constitution was promulgated in 1962, which provisioned for non-party system of councils known as "Panchayat" under which king exercised the sole power. First elections to party less Rastrya Panchayat were held in 1963 to practice the sovereign monarchical Panchayat system in which the sovereignty of the state lied in the hand of the monarchy not the people. The primary aim of the then king to establish a form of "guided democracy" in the name of what was called the Panchayat system was fulfilled which banned political parties, electoral competition, economic and social programs (Panday, 2018). During this period, the natural resources of the country were nationalized from private ownership but communities and the significance of natural resources such as forest for communities were ignored (Gurung, et al. 2011).

The Maoist insurgency that commenced in 1995, one of the reasons of which is elite resource capture, ended in 2006 did not allow taking place of local elections ever since 1997 and the representatives elected in 1997 completed their tenure under threats by 2002 . In the absence of local elected representatives, various mechanisms were introduced as interim arrangements. The decision-making authority was handed to bureaucrats in the beginning and later a mechanism called all party mechanism (APM) was established in 2009 in order to allow bureaucrats to legitimize their decisions and the politics of "Bhagbanda" began introducing massive corruption in the local decisionmaking system. Although the APM was dissolved in 2012 on the accusation of massive 
corruption, the practice of legitimizing local decisions through local leaders of major political parties remained in practice, allowing the bureaucrats to keep their hand on the top of decision-making. Massive corruption, lack of transparency in the decision-making, vertical accountability of bureaucrats and no-horizontal accountability of local politicians weakened local democracy and paralyzed the democratic system of decision-making, program implementation, and evaluation.

In the spirit of achieving transformative development by reducing discrepancies of development disparity in various rural urban regions of Nepal and execute the spirit of the Constitution of 2015, the federal structure was brought into practice with three levels of governments which include: a) 1 federal government; b) 7 provincial governments and; c) $753 \mathrm{rural} /$ urban municipal governments. However, the analysis of Nepal's development history particularly shows that the focus was continuously on political transformation, avoiding issues of human and natural resources development and maximum utility of both human and natural resources were minimalized.

\section{Development History and Emerging Challenges}

Nepal began its plan development system since 1956 by adopting the policy of mixed economy combing the characteristics of both capitalist and social economies, with the end of Ranarchy, by introducing the first five-year plan (GoN, 1956; Dahal, 2005). Planned development tried to divert the resources for uplifting the life of mass, changing socio political condition and demand of time regarding the switch in economic policies. Prior to 1956, the development programs were designed rather on ad-hoc basis. The reviews of periodic plans of Nepal demonstrate that there has been five major turns in the development history of Nepal (Srivastava, 2008). The first turn can be recognized as the introduction of planned development shifting from ad-hoc systems of development. The first development plan prioritized to raise production, employment, standards of living and general well being throughout the country, thus opening out to the people opportunities for a richer and more satisfying life (GoN, 1956). The second major turn can be noticed with the introduction of the fifth development plan designed for the period of 1975 to 1980 . The fifth plan was unique as it recognized poverty, agricultural development, industrial production, social services and population control as the issues of immediate priorities (GoN, 1975). The key objectives of the fifth plan were: i) increase in the production of peoples' requirements; b) maximum utilization of labor power; c) regional development balance and unification of the regions for strengthening the capacity of the state. The fifth plan had some key policy implications, which included investment in production structure for economic stability by mobilizing internal resources, developing labour intensive technology, and industrial arrangement, increasing and diversifying of foreign trade and reforming land ownership and use practices. 
The third major turn takes place with the inception of the eight periodic plan for a period of 1992-1997. The eight periodic five year plan was introduced after the restoration of democracy with a new pattern, changed vision and strategies to meet the desires of people who had fought for the democracy and multi party system for long, setting the objectives of attaining sustainable economic growth, alleviating poverty and reducing regional disparity (GoN, 1992). Privatization, economic liberalization, sustainable economic growth, poverty alleviation, reduction of regional imbalances, disparities between rural and urban areas came to be the important issues of public policy. In this context, the perspectives of this plan are based on two principal contradictory factors. These factors consist of, on the one hand, the positive aspects of the new aspirations and enthusiasm among the general public and, on the other, the negative aspects of the legacy of economic depravity left behind by the Panchayat regime (GoN, 1992). The fourth major turn takes place with the introduction of the Tenth Plan to be implemented for a period from 2002 to 2007. It was considered to be the strategic document for alleviating poverty and its only objective was prioritized on poverty alleviation. The four strategic pillars adopted by the tenth plan for poverty alleviation were a) high, sustainable and broad based economic growth, b) social sector and rural infrastructure development, c) targeted programme and d) good governance (GoN, 2002). The next major turn takes place with the introduction of the Fourteenth Plan being implemented from 2016 to 2019. It has set a target of attaining seven per cent economic growth during this period, creation of employment opportunities with the distribution priority of development plans as per the principle of social justice (GoN, 2016).

The genesis of planned development in Nepal commenced on the year 1956 A.D. Since then fourteenth periodic plans which included four three-year plans and nine fiveyear plans have already been completed and the fourteenth three-year plan is underway implementation process. Historically, the state had been constructed from the top down with little or no interaction, discussion or pressure from organized societal interest, resulting in the public being recipients of policy but not a part of the policy making process. Before policy liberalization in the 1990s, Nepal's policy-making practices emphasized political considerations over economic development. It was only after policy liberalization that Nepal's policy-making practices witnessed rapid changes. First the parliamentary monarchy was established with a system that incorporated public representation through elections in the parliament and on December 28, 2007, the Interim Parliament passed a bill and declared Nepal to become a Federal Democratic Republic. The first meeting of the Constituent Assembly officially implemented that declaration on May 28, 2008. Despite the progressive reform in policy-making, the process has been plagued by slippage and implementation delays arising primarily due to political uncertainty and conflict. Dahal (2005, p. 361) argues that "The modern democratic and 
participatory concepts including good governance has been advocated in Nepalese planning in a highly centralized country which has not yet developed the minimum norms of governance and the nation, consequently, is heading towards bad governance raising serious question of 'failed state".

The federal Constitution of Nepal 2015 schematizes three kinds of functional jurisdictions for three levels of the government. They are the exclusive (enumerated), concurrent and residuary jurisdictions. Cooperative, not competitive type federalism, has been envisaged in terms of distribution of functional jurisdiction where all levels of the government are involved in discharging the same function with different roles and capacity. It is a form of collaborative federalism (marble cake layer federalism), not competitive federalism/ dual federalism. And some discrepancies, overlaps and contradictions exist in the allocation of functions and authority among the three levels of the governments.

The Constitution of Nepal (2015) has provisioned policies relating to protection, promotion and use of natural resources. It stipulates, inter alia, to protect, promote, and make environmental friendly and sustainable use of, natural resources available in the country, in consonance with national interest and adopting the concept of intergenerational equity, and make equitable distribution of fruits, according to the priority and preferential right to the local communities and make multi-purpose development of water resources for reliable clean drinking water, irrigation, and control of water-induced disasters, and river management.

According to the Constitution of Nepal (2015) the Federation, State and Local level shall provide for the equitable distribution of benefits derived from the use of natural resources or development. Certain portions of such benefits shall be distributed, pursuant to law, in forms of royalty, services or goods to the project affected regions and local communities. If, in utilizing natural resources, the local community desires to make investment therein, the Federation, State and Local level shall accord priority to such investment in such portion as provided bylaw on the basis of the nature and size of such investment.

The Constitution of Nepal (2015) has also developed 9 schedules, out of which schedules $6,7,8$, and 9 have provisioned federal, state, local and concurrent powers. The management of natural resources falls within the domain of both federal and state and likely to produce conflicts within provinces in relation to possession of resources and their utilization of province development. Resource conflicts often originate in situations of scarcity wherein the demand for land, forests, water and other resources far outstrips the supply, a situation made worse by demographic pressures, natural disasters, climate change and social inequality (Burnett 2016). Resource conflicts may have class 
Resource Mapping........ Chandra Lal Pandey, Niraj Poudyal, Dipesh Khadka

dimensions, political dimensions, social dimensions and cultural dimensions (Buckles and Rusnak 1999).Therefore, it is necessary to consider seriously and reflect profoundly on questions such as how the states use natural resources in terms of ownership. What kind of decisions regarding natural resources-related issues can maximise the benefits for the provinces, the people and federal Nepal? Federal Nepal must seriously ponder upon potential natural resources conflicts to avoid wars of the kind recently observed in various Indian and Pakistani provinces (Pandey, 2016a).

However, the lack of not having consolidated database system, knowledge gap with elected leaders for the use of authentic and devolved powers, authority and resources, and the long-standing characteristic of Nepal being a centralized unitary system of state for more than 200 years and bureaucracy trained to work in such circumstances, implementing federalism in sustainable manners remain a challenge. The challenges of identification of provincial and local resources still remain a herculean undertaking and through this research, we aim to contribute to the gap of provincial resource mapping index.

\section{Data}

To prepare this paper, we primarily relied on secondary data of Government of Nepal, which were extracted from National Population and Housing Census Report 2011, Central Bureau of Statistics, Nepal Human Development Report 2014, Inland Revenue Department, and the Department of Local Infrastructure Development and Agricultural Roads. We collected following categories data: population, literacy rate (5+year) age group, number of economically active population above 10+age group; per-capita income; road network in kilometer; provincial area in kilometer ${ }^{2}$; forest size in ha; agriculture and grass land in ha; water in ha; total population (10+) in number; and HDI.

The district population data, population data of $(5+$ year) and literacy rate $(5+$ year age group) data were taken from the Nation Population and Housing Census Report 2011, published by Central Bureau of Statistics Nepal. As the separate provincial data were not available, the total population, population data of $(5+$ year) and literacy rate $(5+$ year age group) of Nawalparasi district were equally divided to provinces 4 and 5 . Similarly, the total population, population data of $(5+$ year) and literacy rate $(5+$ year age group) of Rukum district were also equally divided to provinces 5 and 6 . Literacy rate (\%) was calculated by dividing the total number of people in the district who can read and write by the total population of the district, which was 5 years and above.

The economically active population (10+ age group) data was taken from the Statistical Year Book 2015, published by Central Bureau of Statistics of Nepal. The economically active population was the total of usually active population and not usually 
active population out of 10 years of age and over population. As the separate provincial data was not available, the total economically active population of Nawalparasi district was equally distributed to provinces 4 and 5. Similarly, the total economically active population of Rukum district was also equally distributed to provinces 5 and 6 .

The Per capita income (in US dollar) data was taken from the Nepal Human Development Report 2014 jointly published by Government of Nepal, National Planning Commission and United Nations Development Programme. As the separate provincial data was not available, the total per capita income of Nawalparasi district was equally distributed to provinces 4 and 5. Similarly, the total per capita income of Rukum district was also equally distributed to provinces 5 and 6 .

The HDI (2011) data was taken from the Nepal Human Development Report 2014 (Table A4.2) jointly published by Government of Nepal, National Planning Commission and United Nations Development Programme. As the separate provincial data was not available, the HDI of Nawalparasi district was equally distributed to provinces 4 and 5 . Similarly, the HDI of Rukum district was also equally distributed to provinces 5 and 6 .

The road network data in kilometer was extracted form the report titled "Statistics of Local Road network (SLRN) 2016" published by Department of Local Infrastructure Development and Agricultural Roads (DoLIDAR). This data represents the total road network in a district. As the separate provincial data was not available, the total road network of Nawalparasi district was equally divided to provinces 4 and 5. Similarly, the total road network of Rukum district was also equally divided to provinces 5 and 6 .

The area in kilometer ${ }^{2}$ data represents the total area of a district. This data was extracted from the National Population and Housing Census of Nepal 2011, table no.12. As the separate provincial data was not available, the total area of Nawalparasi district is equally divided to provinces 4 and 5. Similarly, the total area of Rukum district was also equally divided to provinces 5 and 6 .

The forest data represents the total forest area in a district. The agricultural land/grass land data represents the total area of agriculture/grass land in a district. The water resource data represents the total area of water bodies in a district. These data were extracted from the report titled 'Compendium of Environment Statistics Nepal 2015', published by Central Bureau of Statistics, Government of Nepal. As the separate provincial data were not available, the total forest area, the total agriculture/grass land area and the total area of water bodies of Nawalparasi district were equally divided to provinces 4 and 5. Similarly, the total forest area and total agriculture/grass land area and the total area of water bodies of Rukum district were also equally divided to provinces 5 and 6. 
The total population (10+ year) data represents the total population of a district which was ten years and above in age. This data was taken from the Statistical Year Book 2015, published by Central Bureau of Statistics of Nepal.

\section{Methods}

The paper develops a resource index $(R I)$ for districts as well as provinces as follows

human $=$ ecoactive $\times$ literacy

ecoactive

$=$ percentage of population 10 years and above who are economically active literacy $=$ percentage of pupulation 5 years and above who can read and write

Multiplying ecoactive by literacy gives the literacy adjusted active population incorporating the human capital aspect of active population. For example, if the literacy rate is only $50 \%$, it is considered as $50 \%$ worth of $100 \%$ literate economically active population in terms of quality of human resource. So, the value of human will be higher either if ecoactive is higher or literacy is higher.

$$
=\frac{\text { forest area }\left(\mathrm{km}^{2}\right) \times \text { agricultural land area }\left(\mathrm{km}^{2}\right) \times \text { water surface area }\left(\mathrm{km}^{2}\right)}{\left(\text { total land area }\left(\mathrm{km}^{2}\right)\right)^{3}}
$$

This measures the amount of natural resources in a province or a district. It is assumed that more forest, agricultural land or water surface area means more natural resources. This cannot exceed 1. If any of the three area is zero (e.g. forest area is 0 ), then the value of natural would be zero.

$$
\text { capital }=\frac{\text { total road length }(\mathrm{km})}{\text { total land area }\left(\mathrm{km}^{2}\right)}
$$

This is the indicator of physical capital available in a district or province. More roads mean more capital resources.

Once the values of human, natural and capital were computed they were normalized so that the lowest value becomes zero and the highest value becomes 1 as follows.

Normalized index $(h, n, k)=\frac{x-\min (x)}{\max (x)-\min (x)}, x=$ human, natural, capital

Now, the value of resource index is given by: 


$$
\begin{aligned}
& R I=\frac{1}{3} \text { human }+\frac{1}{3} \text { natural }+\frac{1}{3} \text { capital } \\
& \text { Normalized } R I=\frac{1}{3} h+\frac{1}{3} n+\frac{1}{3} k
\end{aligned}
$$

Where $0 \leq R I \leq 1$ and $h, n, k \in(0,1)$.

\section{Results}

Results of the computation of the three resource indices are presented below in Table 1. Based on the results in Table 1, basically four types of provinces are identified. Type 1: 2 and 5 (Inefficient); Type 2: 1 and 3 (prosperous); Type 3: 4 (efficient); Type 4: 6 and 7 (resource poor). The average values of the resource index and the HDI are used as thresholds for the categorization. Column "Analysis" is the short analysis of the results and the last column spells brief policy prescriptions for the respective provinces in terms of learning lessons from other provinces.

\section{Table 1}

\begin{tabular}{|c|c|c|c|c|c|c|c|}
\hline Provinces & Human & Natural & Capital & $\begin{array}{l}\text { Normalized } \\
\text { Resource } \\
\text { Index }\end{array}$ & HDI & Analysis & $\begin{array}{c}\text { Policy } \\
\text { prescription }\end{array}$ \\
\hline 1 & 1.000 & 0.584 & 0.578 & 0.721 & 0.553 & $\begin{array}{l}\text { High resource high } \\
\text { performance }\end{array}$ & $\begin{array}{l}\text { Keep it up and } \\
\text { learn from } 4\end{array}$ \\
\hline 2 & 0.000 & 1.000 & 0.836 & 0.612 & 0.485 & $\begin{array}{l}\text { More resource but low } \\
\text { performance }\end{array}$ & $\begin{array}{l}\text { Reduce wastage } \\
\text { and inefficiency }\end{array}$ \\
\hline 3 & 0.787 & 0.508 & 1.000 & 0.765 & 0.560 & $\begin{array}{l}\text { Very high resource high } \\
\text { performance }\end{array}$ & $\begin{array}{l}\text { Keep it up and } \\
\text { learn from } 4\end{array}$ \\
\hline 4 & 0.957 & 0.000 & 0.553 & 0.503 & 0.568 & $\begin{array}{l}\text { Low resources but very } \\
\text { high performance }\end{array}$ & $\begin{array}{l}\text { Outstanding. } \\
\text { Share the } \\
\text { knowledge and } \\
\text { experience. } \\
\text { Should be } \\
\text { supported with } \\
\text { more resources }\end{array}$ \\
\hline 5 & 0.760 & 0.604 & 0.632 & 0.665 & 0.508 & $\begin{array}{l}\text { More resource but low } \\
\text { performance }\end{array}$ & $\begin{array}{l}\text { Reduce wastage } \\
\text { and inefficiency }\end{array}$ \\
\hline 6 & 0.665 & 0.012 & 0.000 & 0.226 & 0.467 & $\begin{array}{l}\text { Low resource and low } \\
\text { performance }\end{array}$ & $\begin{array}{l}\text { Give more } \\
\text { resources and } \\
\text { learn from } 4\end{array}$ \\
\hline 7 & 0.694 & 0.540 & 0.182 & 0.472 & 0.491 & $\begin{array}{l}\text { Low resource and low } \\
\text { performance }\end{array}$ & $\begin{array}{l}\text { Give more } \\
\text { resources and } \\
\text { learn from } 4\end{array}$ \\
\hline Aeverage & 0.954 & 0.501 & 0.553 & 0.577 & 0.519 & & \\
\hline
\end{tabular}

Resource Indices and HDI for the seven provinces

As can be seen in Table 1, Province 3 is the richest province in terms of the three resources considered (in terms of Normalized RI) for this study while as province 6 is poorest on these resources. In terms of outcomes (measured by HDI) Province 3 and 4 are at the top and Province 2 and 6 are at the bottom. 
But the resource richness for each province is different from each other. For example, the poorest province in terms of human resource is Province 2. Province 1, due to its high literacy, is richest in terms of human resources followed by Province 4 . With respect to natural resources, province 2 is the richest one due to its forest coverage. Province 2 comes second in terms of capital resources due to easy road access in its districts. In terms of capital resource, Province 3 is the richest province and Province 6 is the poorest province.

Despite having relatively higher level of resources, HDI outcome of Province 2 is relatively low indicating that resources are being wasted and used inefficiently. On the other hand, Province 4, despite having relatively poor in resources (poorest for natural resources), its HDI is highest among all the provinces. Province 4 is an outstanding province and it needs to share its experience of working efficiently despite having resource constraints with other provinces. Kaski, a district of Province 4, is the outstanding district for its efficient use of limited resources to attain high level of human development.

The computation of the resource index $(R I)$ and its mapping with HDI is presented in graph as follows.

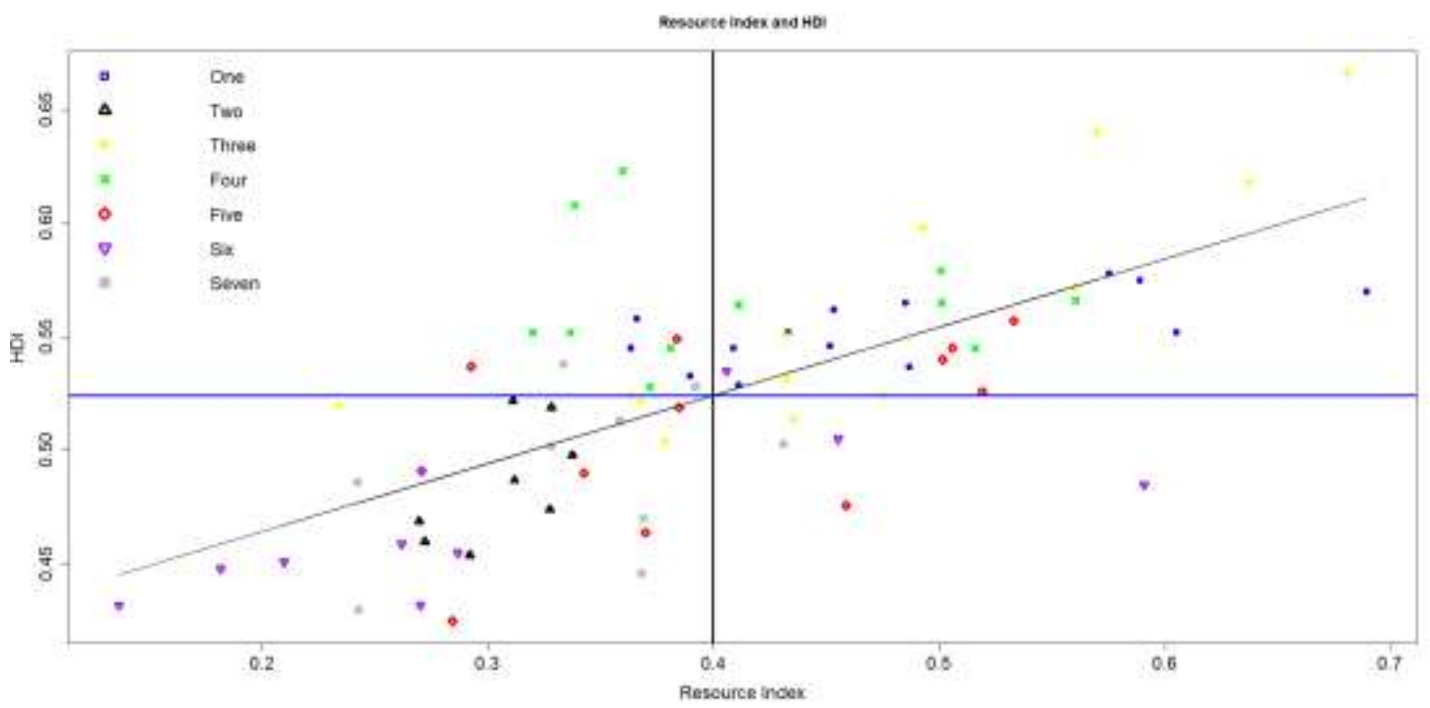

Figure 1: HDI and Resource Index mapped for the districts of Nepal.

Note: Each colored-shape represents different province of Nepal.

A regression analysis is done to evaluate the role of various resources on $H D I$.

Table 2 is the summary of the regression analysis. A linear regression model is estimated using ordinary least square (OLS) method. Province dummy is included. 


\section{Table 2}

Regression Analysis Summary

\begin{tabular}{|c|c|c|c|c|c|c|}
\hline \multirow{2}{*}{ Variables } & \multicolumn{2}{|l|}{ Model 1} & \multicolumn{2}{|l|}{ Model 2} & \multicolumn{2}{|l|}{ Model 3} \\
\hline & Coefficient & $\mathrm{p}$-value & Coefficient & $\mathrm{p}$-value & Coefficient & $\mathrm{p}$-value \\
\hline (Intercept) & 0.548 & 0.000 & 0.458 & 0.000 & 0.466 & 0.000 \\
\hline Province Five & -0.029 & 0.045 & -0.027 & 0.039 & -0.038 & 0.003 \\
\hline Province Four & 0.026 & 0.059 & 0.015 & 0.233 & 0.015 & 0.213 \\
\hline Province One & 0.016 & 0.262 & -0.003 & 0.844 & -0.010 & 0.404 \\
\hline Province Seven & -0.032 & 0.055 & -0.028 & 0.059 & -0.044 & 0.002 \\
\hline Province Six & -0.052 & 0.002 & -0.043 & 0.004 & -0.059 & 0.000 \\
\hline Province Two & -0.061 & 0.003 & -0.017 & 0.346 & -0.042 & 0.005 \\
\hline Working population & -0.053 & 0.388 & & & & \\
\hline Road area & 0.042 & 0.000 & & & & \\
\hline Forest area & -0.003 & 0.867 & & & & \\
\hline Agricultural land area & -0.011 & 0.703 & & & & \\
\hline Water surface area & 0.101 & 0.884 & & & & \\
\hline human & & & 0.090 & 0.001 & & \\
\hline natural & & & 0.009 & 0.742 & & \\
\hline capital & & & 0.105 & 0.000 & & \\
\hline$R I$ & & & & & 0.204 & 0.000 \\
\hline$R^{2}$ & 0.668 & & 0.715 & & 0.685 & \\
\hline$N=77$ & & & & & & \\
\hline
\end{tabular}

In Table 2, bold coefficients are the significant explanatory variables that explain the variation in HDI. Province 3 is used as base category in the regression model. If positive, the coefficients of other provinces can be interpreted as being more than that of Province 3. It turns out that natural resources are not statistically significant determinants of a district's HDI whether the resources are used as regressors separately or as indices. The two resources: capital and human are highly significant to explain the variation in HDI. More capital and human resources would mean significantly higher HDI. When all the resource variables are replaced by the $R I$, the value of $\mathrm{R}^{2}$ reduces from 0.715 to 0.685 , which is substantively insignificant, indicating that the $R I$ represents all the resources considered for this study.

\section{Discussion}

The planned development of Nepal which began from 1956 has already completed a journey of over six decades. Issues of fundamental civil rights, ensuring social justice, finding paths towards achieving economic development, and making societies prosperous are the primary items in the development agenda of Nepal (GoN, 2016). There has been a paradigm shift in relation to political system in Nepal, transforming from Monarchy to a Federal Republic. The Nepali model of federalism is unique from many other countries of the world for its very characteristics of collaborative 
and cooperative models of federal, provincial and local governments. Reviews of federalism in global scale today show that political, cultural, economic, and social change are undergoing at an unprecedented rate, and federal countries are experiencing continuous transformation (Blindenbacher and Saunders, 2005). They are therefore faced with the need to develop an ability to learn and adapt in order to cope with the challenges they face. Although the circumstances in each federation are different, many of the problems they face are common - about resources - to all.

In this section, we discuss the experiences of other federations to allow us to foresee more clearly the likely consequences of various arrangements and resources availability and unavailability and potential transformative development opportunities in the provinces of Nepal. We limit this study to focus on three federal governments only (Canada, Nigeria and India) and the challenges they are confronting.

The constitution of Canada divides power between the federal and provincial governments as well as the territories. The federal government holds sole authority to regulate certain activities in trade, transportation, commerce and environmental issues. Land related matter is handled through the use of land right treaties or land claims (Andre Lecours, 2009). Canada provides jurisdictive authority to provincial and territorial governments in matters relating to property rights, electricity and natural resources. Although Canada has ten provinces particularly Ontario, Quebec, Alberta, and British Columbia often challenge the federal government of Ottawa because, in the Canadian context, they are political centers of power supported by important social, economic, and human and natural resources (Esman, 1984). In Canada, conflicts over oil and gas revenues and prices between producing and consuming regions and between federal and provincial governments have become prominently contested issues since the early 1970s (Simeon, 1980). The British Columbia province tops the provinces with an excellent overall performance in Canada followed by Ontario and resource-rich Alberta, and Saskatchewan (The Conference Board of Canada, 2017), indicating that having appropriate and effective human and natural resources can provide economic liberty of one province to others.

Nigeria has thirty-six states divided through eight times amendment. The conflicts of resource control are historically a germane issue in Nigerian government and politics. This is largely because of the value attached to resources by the government and the people whose land the resources are domiciled (Shebbs\& Njoku, 2016). Although Nigeria is rich in relations to natural resources primarily oil, the resource control system in Nigeria is not having a positive impact on the lives of the people, which forms the basis for most resource conflicts in the inter-state and inter-regions of the country. "There is a strong indication that things have gone absolutely wrong with the way resources are being controlled in Nigeria. But there can be a turnaround when there is an integrative action toward achieving democratic goals for the local communities" (Shebbs\& Njoku, 2016). The North-South divisions of Nigeria along with the states located in these areas enjoy or lose the opportunity of being resourceful or non-resourceful in their development plans and provincial prosperity. The northern region has abundance of natural resources yet the southern region and provinces perform better in relation to 
development and HDI. The response to why the southern provinces benefit more than the northern ones could be that the existence of federal government is in the south, which is flushed with oil rents, promotion of service-sector industries and continuous exploitation of natural and human resources available in the provinces and in the northern region (Dapel, 2018), leading to establish Boko Haram, an armed group, to push the country in war.

Likewise, Indian federal constitutional republic consists of 29 statesand 7 union territories. India is the world's third-largest producer of iron ore and coal. Mining is one of the most lucrative resource businesses in India, causing conflicts and displacing people to exploit their land (Ghatak, 2012). The interstate wars over resources are becoming common in India. Since India acquired independence, a large number of inter-state water disputes cropped up over the use of rivers (Gautam, 1976) and the latest one was on the issue of water resources between Tamil Nadu and Karnataka in 2017 (Pandey, 2016a). Maharashtra is the richest state with GDP of US\$ 233 billion followed by Uttar Pradesh and Andra Pradesh. Although Maharashtra is not very rich in terms of natural resources, its second largest size of population, high level investment in quality education, inclusive development approach prioritizing agriculture, industry and services, good quality fertile land and plenty of rain creates an enabling condition for it to be the highest GDP earning state in India.

The availability of qualified high-quality human resources and abundance of natural resources are the major indicators to become a state resourceful and developed, however, having abundance of resources without having vibrant and high-quality human resources may not always result in to be one of the best performing states in relation to economic efficiency and good HDI. In this context, our study found that having abundance of natural resources alone or human resources alone in isolated patterns might not result in to best performance of any province. We found that province 3 is the richest province in terms of the three resources considered for this study while as province 6 is poorest on these resources. In terms of outcomes (measured by HDI) Province 3 and 4 are at the top and Province 2 and 6 are at the bottom. While province 2 has relatively higher level of resources, its HDI outcome of is relatively low indicating that resources are being wasted and used inefficiently, on the other hand, province 4, despite having relatively poor in resources (poorest for natural resources), its HDI is highest among all the provinces. Province 4 is an outstanding province and it needs to share its experience of working efficiently despite having resource constraints with other provinces. Kaski, a district of Province 4, is the outstanding district for its efficient use of limited resources to attain high level of human development.

\section{Conclusion}

This study presented that the negligence of natural resources and human capital in the history of Nepal's political development and transformation has impacted the overall development of Nepal. The global literature reviews conducted for this study and our resource index concomitantly demonstrate that to be the best performing province, having natural resources alone or human resources alone in isolated patterns are not enough rather if they evolve in integrated patterns interacting with one another with highly 
Resource Mapping........ Chandra Lal Pandey, Niraj Poudyal, Dipesh Khadka

skilled human resources can lead the provinces to provincial prosperity leading to fulfill national interest of graduating Nepal from least developed country to developing one. Our study concluded that although province 4 is average in terms of possessing natural resources, investment in education and availability of high skilled human resources excelled all other provinces, which possess abundance of natural resources and immense population size.

\section{References}

Andre Lecours, D. B. (2009). Federalism and Fiscal Policy: The Politics of Equalization in Canada. The Journal of Federalism. Vol. 40: 569-596.

Blindenbacher, Raoul and Saunders, Cheryl. 2005. A Global Dialogue on Federalism: Conceptual Framework. In A Global Dialogue of Federalism, edited by Raoul Blindenbacher and Abigail Ostien, pp. 2-7. London: McGill-Queen's University Press.

Buckles, Daniel and Rusnak, Garett. (199). Conflict and Collaboration in Natural Resources Management in Cultivating Peace: Conflict and Collaboration in Natural Resource Management, Daniel Buckles (ed), 1-12. Canada: International Development Research Centre \& World Bank.

Burnett, M. T (2016) Natural Resource Conflicts: From Blood Diamonds to Rainforest Destruction. California: ABC-CLIO Publisher.

CBS. (2015). Compendium of Environment Statistics Nepal. Kathmandu: CBS.

CBS. (2015). Statistical Year Book Nepal. Central Bureau of Statistics, National

Planning commission Secretariat. Kathmandu: Central Bureau of Statistics.

Central Bureau of Statistics (CBS). (2011). National Population and Housing Census.

Central Bu reau of Statistics, National Planning Commission Secretariat.

Kathmandu: CBS.

Dahal, Ram Kumar. 2005. Rural Development Politics in Nepal: A Study in State, Society, Good Governance, Decentralization, Civil Society, Local Governance and Rural Development. Kathmandu: Dikshanta Pustak Prakshan.

Dapel, Zuhumnan. 2018. Poverty in Nigeria: Understanding and Bridging the Divide between North and South. Washington DC: Center for Global Development. Retrieved from:

Department of Local Infrastructure Development and Agricultural Roads (DoLIDAR). (2016). Statistics of Local Road Network. Kathmandu: DoLIDAR.

Encyclopedia Britannica. 2018. Nepal since 1990. New South Wales: Encyclopedia Britannica Australia Ltd. Available at: https://www.britannica.com/place/Nepal/Nepal-since-1990.

Esman, Milton J. 1984. Federalism and Modernization: Canada and the United States. The Journal of Federalism. Vol. 14: 21-38.

Gautam, Sid. 1976. Inter-State Water Disputes: A Case Study Of India. Water Resources Bulletin. Vol. 12 (5): 1061-1070.

Ghatak, Aditi Roy. 2012. State of Conflict. Development and Cooperation. Vol. 6: 234. Retrieved from: https://www.dandc.eu/en/article/some-regions-india-face-sameproblems-resource-rich-fragile-states-have 
GoN. 1956. First Periodic Plan of Nepal, 1956-1960. Kathmandu: Government of Nepal. GoN. 1975. Fifth Periodic Plan of Nepal, 1975-1980. Kathmandu: Government of Nepal.

GoN. 1992. Eighth Periodic Plan of Nepal, 1992-1997. Kathmandu: Government of

Nepal.

GoN. 2002. Tenth Periodic Plan of Nepal, 2002-2007. Kathmandu: Government of Nepal.

GoN. 2016. Fourteenth Periodic Plan of Nepal. 2016-2019. Kathmandu: Government of Nepal.

GoN. 2015. Constitution of Nepal 2015. Kathmandu: Government of Nepal.

Gurung, Anup., Karki, Rahul. andBista, Rajesh. 2011. Community Based Forest

Management in Nepal: Opportunities and Challenges. Resources and

Environment.Vol. 1 (1): 26-31.

National Planning Commission, United Nations Development Programme. (2014). Nepal Human Development Report. Kathmandu: Government of Nepal, National Planning Commission and United Nations Development Programme.

Panday, Devendra Raj. 2018. The Idea of Integrity and the Universe of Corruption and Anticorruption. Kathmandu: Redink Books.

Pandey, Chandra Lal. 2017a. 'The 2015 Nepal Earthquake: From Rescue to Reconstruction'. In Recovering from Catastrophic Disaster in Asia, edited by William L. Waugh and Ziqiang Han, 161-176. Bingley, UK: Emerald Publishing. Pandey, Chandra Lal. 2016a. My Water Your Water. Kathmandu: Kathmandu Post.

Retrieved from http://kathmandupost.ekantipur.com/news/2016-11-15/my-wateryour-water.html

Pandey, Chandra Lal. 2016b. Resource Conflicts and Conflict Management: Practices and Challenges in Nepal. Journal of Conflict, Peace and Development

Studies. Vol. 3 (JOCPDS), Volume 2: 35-52.

Shebbs, Emmanuel U. \& Njoku, Ray. 2016. Resource control in Nigeria- issues of politics, conflict and legality as challenge to development of the Niger delta region. Vol. 3 (3): 32-45.

Simeon, Richard. 1980. Natural Resource Revenues and Canadian Federalism: A Survey of the Issues. Canadian Public Policy. 182: 191.

Srivastava, Nagendra Lal. 2008. Major Turns in Planned Development of Nepal. The Journal of Nepalese Business Studies. Vol. 5 (1): 1-15.

The Conference Board of Canada. 2017. Provincial and Territorial Ranking. Retrieved from

https://www.conferenceboard.ca/hcp/provincial/economy.aspx?AspxAutoDetectC ookieSupport $=1$ 